Article

\title{
Integrated GIS-Based Multi-Criteria Analysis for Groundwater Potential Mapping in the Euphrates's Sub-Basin, Harran Basin, Turkey
}

\author{
Veysel Aslan ${ }^{1}$ and Recep Çelik ${ }^{2, *(1)}$ \\ 1 Construction Technology, Hilvan Vocational School, Hilvan Harran University, 63900 Şanlıurfa, Turkey; \\ vaslan@harran.edu.tr \\ 2 Civil Engineering Department, Engineering Faculty, Dicle University, 21280 Diyarbakır, Turkey \\ * Correspondence: recep.celik@dicle.edu.tr; Tel.: +90-412-248-84-01 (ext. 3547)
}

\section{check for}

updates

Citation: Aslan, V.; Çelik, R. Integrated GIS-Based Multi-Criteria Analysis for Groundwater Potential Mapping in the Euphrates's

Sub-Basin, Harran Basin, Turkey. Sustainability 2021, 13, 7375. https:// doi.org/10.3390/su13137375

Academic Editors: Mohammed Mainuddin, Mohammad A. Mojid, Sreekanth Janardhanan and Hone-Jay Chu

Received: 30 March 2021

Accepted: 25 June 2021

Published: 1 July 2021

Publisher's Note: MDPI stays neutral with regard to jurisdictional claims in published maps and institutional affiliations.

Copyright: (c) 2021 by the authors. Licensee MDPI, Basel, Switzerland. This article is an open access article distributed under the terms and conditions of the Creative Commons Attribution (CC BY) license (https:// creativecommons.org/licenses/by/ $4.0 /)$.

\begin{abstract}
The Harran Basin is an important region where agricultural activities have been conducted for millennia. The agricultural water needs of the basin are largely met with surface irrigation through the GAP (South-Eastern Anatolian Project), while groundwater is used in some regions as potable water, tap water, and irrigation water. In this study, the groundwater potential of the Harran Basin was determined through the "GIS-based Multi-Criteria Decision Making (MCDM)" Method. Ten criteria were considered: Land Use, Soil, Geomorphology, Geology, Aquifer, Drainage Density, Rainfall, Slope, Lineament Density, and Terrain Class. The weights of these criteria were determined through the AHP method, and the operations were performed in the ArcGIS environment. As the results of this study, the Groundwater Potential Index (GWPI) values were obtained, and five regions were determined based on their Groundwater Potential Zone (GWPZ) classifications: very poor GWPI: $0.10 \%$ (5.14 km²); poor GWPI: $29.20 \%$; moderate GWPI: $38.20 \%$; good GWPI: $30.90 \%$; and very good GWPI: $1.50 \%$ ). We determined that the region is a plain with a low slope and geologically consists of limestone. Notably, areas with poor water potential are mountainous and hilly, and the slopes over these areas are high.
\end{abstract}

Keywords: groundwater-potential zone; multicriteria decision making; GIS; Analytic Hierarchy Process (AHP); Euphrates's sub-basin

\section{Introduction}

The Harran Basin hosted some of the oldest agricultural activities in history. Settlement in the basin began approximately 11,000 years ago [1], and there has been a continuous settlement in the basin since the Neolithic period [2]. In this timeframe, the basin has witnessed regular agriculture and stockbreeding activities. Here, the existence of ample water resources is as important for human life and agricultural activities as appropriate climatic conditions and a physical environment with fertile lands [3,4]. Since agriculture accounts for $19 \%$ of the gross national income and $9 \%$ of exports and provides employment opportunities for $51 \%$ of the population, agriculture plays an important social and economic role in the lives of the people in Turkey. Here, irrigated farming has a higher value due to the geographical location of Turkey, its demographic structure, and its economic determination. Today, the Harran basin is one of the most important regions that hosts irrigated farming in Turkey [5]. While the majority of the Harran Basin has the opportunity to engage in surface irrigation under the GAP [6], due to unconscious irrigation, agricultural activities are conducted with groundwater in the south-southeast sections of the basin. However, groundwater provides important water resources as an alternative for a possible surface water shortage. Studies on groundwater and drought indicate the importance of properly determining the groundwater potential [7-9]. On the other hand, groundwater is being used as potable water and tap water in some of the rural settlements in the basin. 
Therefore, it is important to determine the groundwater potential of the basin. Since the 1950s, groundwater levels in agricultural areas in several regions have fallen by as many as $50 \mathrm{~m}$ [10], and groundwater-dependent rivers, wetlands, and ecosystems have been compromised. The increase in the use of unplanned groundwater destabilizes the balance of natural recharge [11,12]. In general, the excessive use of aquifers leads to serious impacts on the environment and ecology, such as aquifer depletion, low-quality water migration, land subsidence, and the destabilization of the economic balance of the region [13-15].

The Groundwater Potential Index (GWPI) is a coefficient that indicates the groundwater potential of a region. This coefficient is obtained from the weights of the criteria comprising the groundwater potential through the "GIS-Based Multi-Criteria Decision Making (MCDM)" method [16-18]. GWPI is used to describe the possibility of obtaining groundwater resources in a region. The GWPI of a region varies according to the characteristics of the groundwater potential and its weighted importance coefficient. GWPIs provide remote sensing data and a possible assessment of the groundwater resources based on the integration of the criteria which impact on groundwater potential occurrence under the GIS environment. GWPI can also be defined through a sufficient number of water driller logs analyzed with hydrological and geophysical surface explorations [19-21]. However, these methods are time-consuming and expensive. Therefore, for the appropriate estimation of groundwater potential in a region, besides a limited number of field observations, Remote Sensing (RS) views and/or GIS data and software can be used [22-24]. In a multi-criteria decision-making process, Geographical Information System (GIS) can effectively produce a qualitative estimate of the groundwater resources [25-29].

Previous studies conducted on the groundwater potential in the Harran Basin are either too old [30] or were conducted locally with limited data [31]. More broadly, we found no study in the literature that analyzed groundwater potential on a basin basis. In the basin, groundwater potential studies were instead conducted on contamination based on agricultural activities [32-34] and the quality of groundwater [35]. The smaller number of studies conducted on groundwater potential is a vital deficiency in the Harran Basin, which is one of the most fertile basins in the Middle East. One of the objectives of this study is to fill this gap.

To obtain groundwater potential maps of the Harran Basin, a multi-criteria decisionmaking process was used together with a hydrological model. In defining the groundwater potential, the ArcGIS 10.2.2 program and GIS tools such as Spatial analysis and Arc Hydro were used in this study to create an AHP (Analytical Hierarchy Process). Influencing the groundwater resource flow, ten criteria were taken into consideration: Land Use, Soil, Geomorphology, Geology, Aquifer, Drainage Density, Rainfall, Slope, Lineament Density, and Terrain Class. The relative weights of each criterion were determined through the AHP-MCDM method, and thematic maps of the Harran Basin groundwater potential were obtained through the Spatial Analysis Overlay method based on these weight values. The obtained results were then compared with the data of the 18 water-wells previously established in the region and were confirmed to a large extent.

\section{Materials and Methods}

\subsection{Study Area}

The Harran Basin is part of the Upper Euphrates Basin and is located in the Southeast Anatolia Region of Turkey, to the south of Sanliurfa province. Stretching from north to south toward the Syrian border, the research area is located at a Latitude of $37^{\circ} 20^{\prime}$ and a Longitude of $39^{\circ} 30^{\prime} \mathrm{E}, 38^{\circ} 30^{\prime} \mathrm{W}$ (Figure 1). 


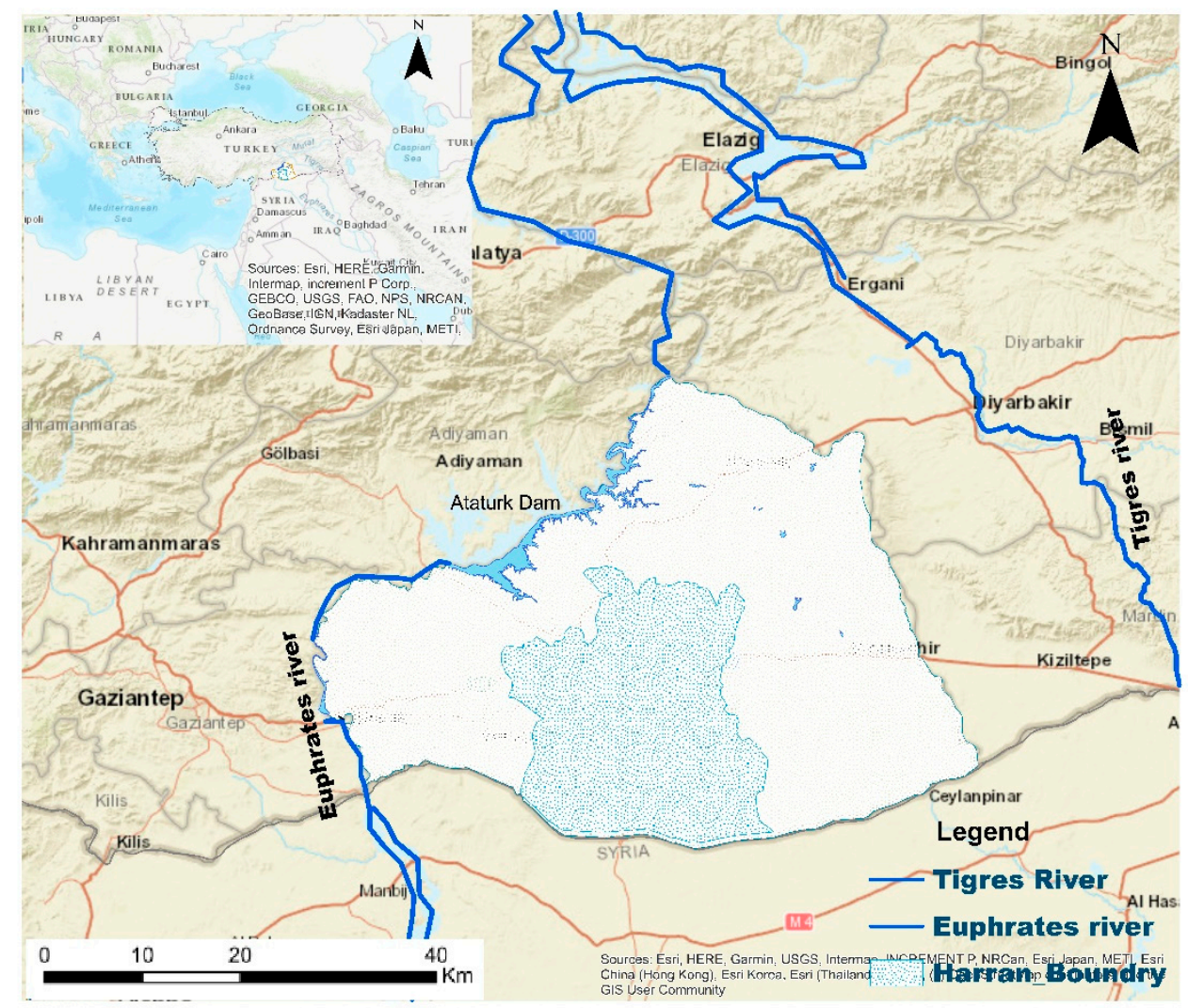

Figure 1. Harran Basin Research Area Location Map (Şanlıurfa), Turkey.

The average elevation is $500 \mathrm{~m}$ in the north, which decreases to $350 \mathrm{~m}$ in the south on the Turkey-Syria border. The basin is separated from the Ceylanpinar Basin with the Tektek Mountains in the east and from the Suruç Basin with the Urfa Mountains. The northern part of the region is quite uneven and hilly. However, there is a limitation in the east-west direction. The Tektek Mountains to the east rise up to 600-700 m, while the altitude increases to $800 \mathrm{~m}$ in the Urfa Mountains to the west. As in the North, hills reaching an altitude of $850 \mathrm{~m}$ surround the plain. The region has a continental semi-arid climate, and the 40-year rainfall average of the Harran Basin is approximately $332.3 \mathrm{~mm}$. The research area comprises approximately $5144.4 \mathrm{~km}^{2}$ of the basin drainage area, which includes the Şanlıurfa province, Harran, and the Akcakale districts. In the basin, grain and cotton growing are the primary agricultural activities, and the economy in the region is based on agriculture and stockbreeding.

As a north-south graben, the Harran basin is surrounded with Eocene epoch limestones to the east, west, and north. The Akcakale graben is one of the last productions of the severe tectonism that occurred during and after the Miocene period in Southeast Anatolia. Although the initial products of compressive motions were stretched in an eastwest direction, the fault systems and structural axis comprising this graben are oriented approximately in a north-south direction [36]. The limestones surrounding the east and west of the basin stretch toward the plain with a high slope due to faulting. The slopes to the north, northeast, and northwest are oriented toward the plain, with an average gradient of $15-25 \%$. The slope decreases toward the south and becomes too small to observe toward the Turkey-Syria border. The mostras are covered by upper red clay, and the baseline of the basin is formed by the topography of these limestones [30].

\subsection{Method}

Determining the groundwater potential using MCDM with the CBS software has become a commonly used method in recent years [37-41]. Groundwater potential is based on numerous parameters such as rainfall, geology, type of soil, use of land, and 
slope [42-46]. In this study, ten criteria were considered to determine the GWPI: use of land, land structure, slope, geology, hydrogeology, geomorphology, soil map, drainage density, fault density, and rainfall parameters. The flowchart shown in Figure 2 summarizes the transactions. Initially, the feature maps of all the criteria were converted to the raster format, and the thematic maps were subsequently re-classified according to their weighted values, determined through the AHP method.

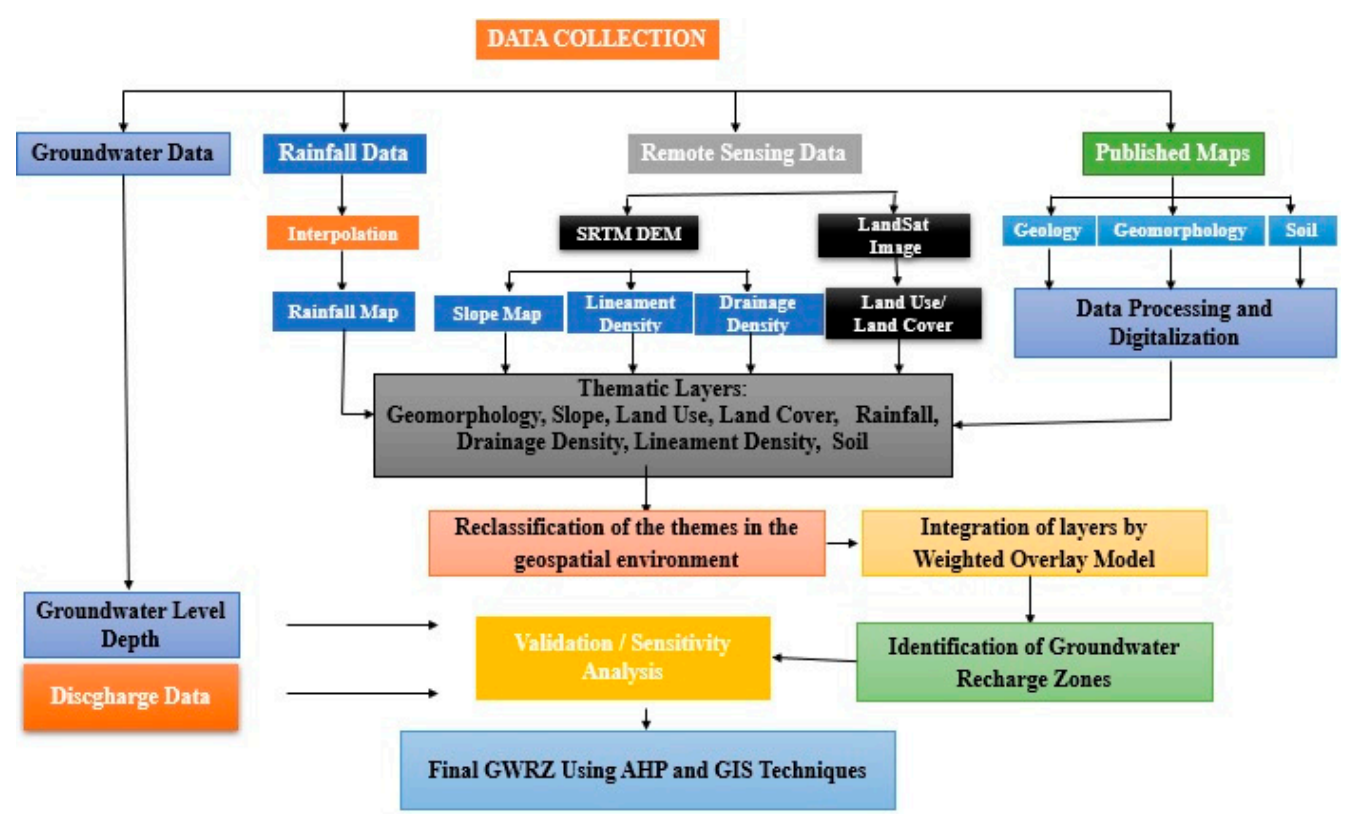

Figure 2. Hierarchical flowchart for the mapping of the Harran Basin's groundwater potential.

The methods for obtaining these parameters are summarized in Table 1. The use of land (Figure 3a) was obtained from the "Global Land Cover Facility" site in the Erdas image format and converted according to the CORRINE method. Moreover, the soil type characteristics (Figure $3 \mathrm{~b}$ ) were appropriately obtained after processing data from the Ministry of Agriculture's official website. The DEM maps were obtained from the Turkey $\mathrm{N} 43$ and N441/100,000 topography maps. These maps were digitized in a $10 \times 10 \mathrm{~m}$ resolution. We produced Geomorphology (Figure 3c) from DEM maps. Geology (Figure 3d) and active Fault maps (Figure $3 \mathrm{~h}$ ) were digitized in the $\mathrm{kml}$ format using the online data system on the MTA website; these maps were subsequently converted via the ArcGIS Data Interoperability program to the shp format. Using these DEM maps and the Spatial Analysis and Arc-Hydro modules in the ArcGIS 10.2.2 software, Drainage Density Maps (Figure 3f) and Slope (Figure 3j). These two maps were initially converted to raster maps with ArcGIS and subsequently re-classified according to the impacts of the basement layers on the formation of groundwater potential. Annual rainfall values between 1971 and 2017 were obtained from the official website of the State Meteorological Services department, and the rainfall maps of all the regions were obtained with these data through the ArcGIS "Inverse Distance Weight" (IDW) method (Figure 3g). 
Table 1. Data Sources.

\begin{tabular}{ccc}
\hline Parameter & Data Source & Mode of Processing \\
\hline Slope (S) & Topographic maps (N43, N44 layouts): 1/100,000), DEM & Digitalization/3D analyst ArcGIS \\
\hline Lineament Density & Geological map,mta.gov.tr online maps & $\begin{array}{c}\text { Online digitalization in .kml format, converted } \\
\text { to .shp file via the Data Interoperability ext. }\end{array}$ \\
\hline Geology & Geological maps; map,mta.gov.tr online maps & $\begin{array}{c}\text { Online digitalization in .kml format, converted } \\
\text { to .shp file via the Data Interoperability ext. }\end{array}$ \\
\hline Geomorphology & DEM maps, topographic maps & Digitalization/3D analyst ArcGIS/classification \\
\hline Land Use (LU) & Landsat\&imagery & Classification in ENVI \\
\hline Soil Type & (https://www.tarim.gov.tr (accessed on & 1 December 2020)) \\
\hline Rainfall (R) & Turkish State Meteorological Service & Digitalization/classification in ArcGIS \\
\hline Drainage Density & DEM maps, topographic maps & Interpolation/classification \\
\hline
\end{tabular}
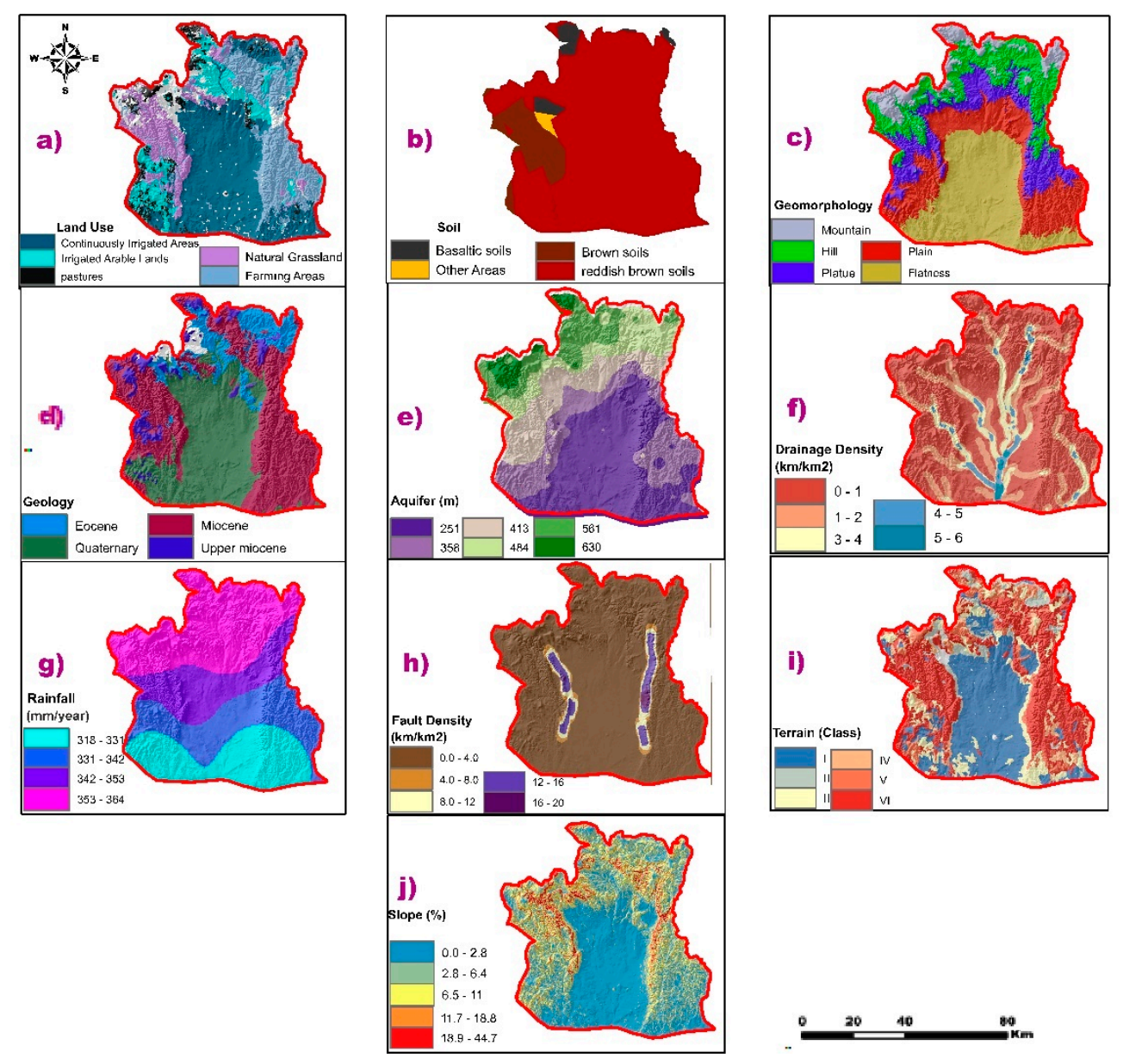

Figure 3. Main criteria affecting the reclassified Groundwater Potential Index (GWPI) raster maps ((a): Land Use, (b): Soil, (c): Geomorphology, (d): Geology, (e): Aquifer, (f): Drainage Density, (g): Rainfall, (h): Fault (Lineament) Density, (i): Terrain Class, and (j): Slope).

Ultimately, the Groundwater Potential Index (GWPI) was shaped with the Overlay Sum using the relative weighted values of each parameter. To define the regions with groundwater potential, the standard index approach was used. 


\section{GIS-Based AHP Method}

The analytical hierarchy process is a quantitative method that involves sorting and selecting decision alternatives according to multiple criteria [47]. This method was developed by Saaty $[48,49]$ and is based on three principles: sortation, relative decision, and a combination of preferences [48]. Analytic Hierarchy Process (AHP) can be applied to estimate the weights $(\mathrm{W})$ of all parameters influencing groundwater potential through the MCDM method. The 1-9 scale of the AHP (1: extremely insignificant, 2: very insignificant, 3: insignificant, 4: reasonably insignificant, 5: equally significant, 6: reasonably significant, 7: more significant, 8: very significant, and 9: extremely significant) was used to shape the decision matrices [50].

Subsequently, the Decision Making Matrix was shaped by paired comparisons (Table 2). Then, the relative weights $(\mathrm{W})$ of the criteria were calculated (Table 3$)$.

Table 2. Pairwise Comparison Matrix with Analytic Hierarchy Process (AHP).

\begin{tabular}{ccccccccccc}
\hline & LU & S & GM & G & A & DD & R & SL & LD & TC \\
\hline Land Use & 1.00 & 0.86 & 0.75 & 0.75 & 0.75 & 1.00 & 0.67 & 0.75 & 1.50 & 1.00 \\
Soil & 1.17 & 1.00 & 0.88 & 0.88 & 0.88 & 1.17 & 0.78 & 0.88 & 1.75 & 1.17 \\
Geomorphology & 1.33 & 1.14 & 1.00 & 1.00 & 1.00 & 1.33 & 0.89 & 1.00 & 2.00 & 1.33 \\
Geology & 1.33 & 1.14 & 1.00 & 1.00 & 1.00 & 1.33 & 0.89 & 1.00 & 2.00 & 1.33 \\
Aquifer & 1.33 & 1.14 & 1.00 & 1.00 & 1.00 & 1.33 & 0.89 & 1.00 & 2.00 & 1.33 \\
Drainage Density & 1.00 & 0.86 & 0.75 & 0.75 & 0.75 & 1.00 & 0.67 & 0.75 & 1.50 & 1.00 \\
Rainfall & 1.50 & 1.29 & 1.13 & 1.13 & 1.13 & 1.50 & 1.00 & 1.13 & 2.25 & 1.50 \\
Slope & 1.33 & 1.14 & 1.00 & 1.00 & 1.00 & 1.33 & 0.89 & 1.00 & 2.00 & 1.33 \\
Lineament Density & 0.67 & 0.57 & 0.50 & 0.50 & 0.50 & 0.67 & 0.44 & 0.50 & 1.00 & 0.67 \\
Terrain class & 1.00 & 0.86 & 0.75 & 0.75 & 0.75 & 1.00 & 0.67 & 0.75 & 1.50 & 1.00 \\
\hline
\end{tabular}

LU: Land Use, S: Soil, GM: Geomorphology, G: Geology, A: Aquifer, DD: Drainage Density, R: Rainfall, SL: Slope, LD: Lineament Density, TC: Terrain Class.

Table 3. Normalized Criteria Matrix with AHP.

\begin{tabular}{|c|c|c|c|c|c|c|c|c|c|c|c|}
\hline & $\begin{array}{l}\text { Land } \\
\text { Use }\end{array}$ & Soil & GM & Geology & Aquifer & DD & Rainfall & Slope & LD & $\begin{array}{c}\text { Terrain } \\
\text { Class }\end{array}$ & $\mathbf{W}$ \\
\hline Land Use & 0.09 & 0.09 & 0.09 & 0.09 & 0.09 & 0.09 & 0.09 & 0.09 & 0.09 & 0.09 & 0.09 \\
\hline Soil & 0.10 & 0.10 & 0.10 & 0.10 & 0.10 & 0.10 & 0.10 & 0.10 & 0.10 & 0.10 & 0.10 \\
\hline Geomorphology & 0.11 & 0.11 & 0.11 & 0.11 & 0.11 & 0.11 & 0.11 & 0.11 & 0.11 & 0.11 & 0.11 \\
\hline Geology & 0.11 & 0.11 & 0.11 & 0.11 & 0.11 & 0.11 & 0.11 & 0.11 & 0.11 & 0.11 & 0.11 \\
\hline Aquifer & 0.11 & 0.11 & 0.11 & 0.11 & 0.11 & 0.11 & 0.11 & 0.11 & 0.11 & 0.11 & 0.11 \\
\hline Drainage Density & 0.09 & 0.09 & 0.09 & 0.09 & 0.09 & 0.09 & 0.09 & 0.09 & 0.09 & 0.09 & 0.09 \\
\hline Rainfall & 0.13 & 0.13 & 0.13 & 0.13 & 0.13 & 0.13 & 0.13 & 0.13 & 0.13 & 0.13 & 0.13 \\
\hline Slope & 0.11 & 0.11 & 0.11 & 0.11 & 0.11 & 0.11 & 0.11 & 0.11 & 0.11 & 0.11 & 0.11 \\
\hline Lineament Density & 0.06 & 0.06 & 0.06 & 0.06 & 0.06 & 0.06 & 0.06 & 0.06 & 0.06 & 0.06 & 0.06 \\
\hline Terrain Class & 0.09 & 0.09 & 0.09 & 0.09 & 0.09 & 0.09 & 0.09 & 0.09 & 0.09 & 0.09 & 0.09 \\
\hline
\end{tabular}

$\lambda_{\max }=8.12, \mathrm{CI}=0.02, \mathrm{RCI}=1.41, \mathrm{CR}=0.011<0.1:$ acceptable.

The application of the GIS technique and multicriteria decision analysis provides more flexible solutions for the prediction of groundwater-potential zones.

In this study, the weighting of various criteria was carried out through field analysis and a literature review. The basic steps for determining the system's normalized weight and consistency ratio $(\mathrm{CR})$ were as follows:

Step 1. Establishment of judgment matrices (p) by pairwise comparison:

$$
\mathrm{p}=\left|\begin{array}{cccc}
p_{11} & p_{12} & \ldots & p_{1 n} \\
p_{21} & p_{22} & \ldots & p_{2 n} \\
\ldots & \ldots & \ldots & \ldots \\
p_{n 1} & p_{n 2} & \ldots & p_{n n}
\end{array}\right|
$$


where $p_{n}$ displays the $n$-th indicator unit, and $p_{n n}$ is the judgment matrix element.

Step 2. Calculation of the normalized weight:

$$
W n=\left(G M n / \sum_{n=1}^{N} G M n\right)
$$

where $W$ is the weight vector (column), and GMn is the geometric mean of the $i$-th row of the judgment.

Step 3. $C R$ calculation to verify the coherence of the judgements:

$$
C R=C I / R C I .
$$

The Consistency Index $(C I)$ is denoted as follows:

$$
C I=\frac{\lambda_{\max }-N}{N-1}
$$

where $\lambda_{\max }$ is the eigenvalue of the judgment matrix, which is calculated as follows:

$$
\lambda=\frac{\sum_{i=1}^{n}(P i . W) n}{\text { N.W }}
$$

The Random Consistency Index (RCI) was then obtained from standard tables [51]. To be accepted, the CR value was required to be about 0.10 or less.

\subsection{Groundwater Potential Index (GWPI)}

GWPI is the size that demonstrated the groundwater potential in a certain region. It is calculated by considering the weight of each criterion that constitutes the GWPI. Thus, determinations can be made about the groundwater potential of various parts of a region [52]. Therefore, a general assessment can be made by classifying the GWPI value ranges as poor-normal-good-very good. This map is the conclusion map of the study, and it is demonstrated in Figure 4.

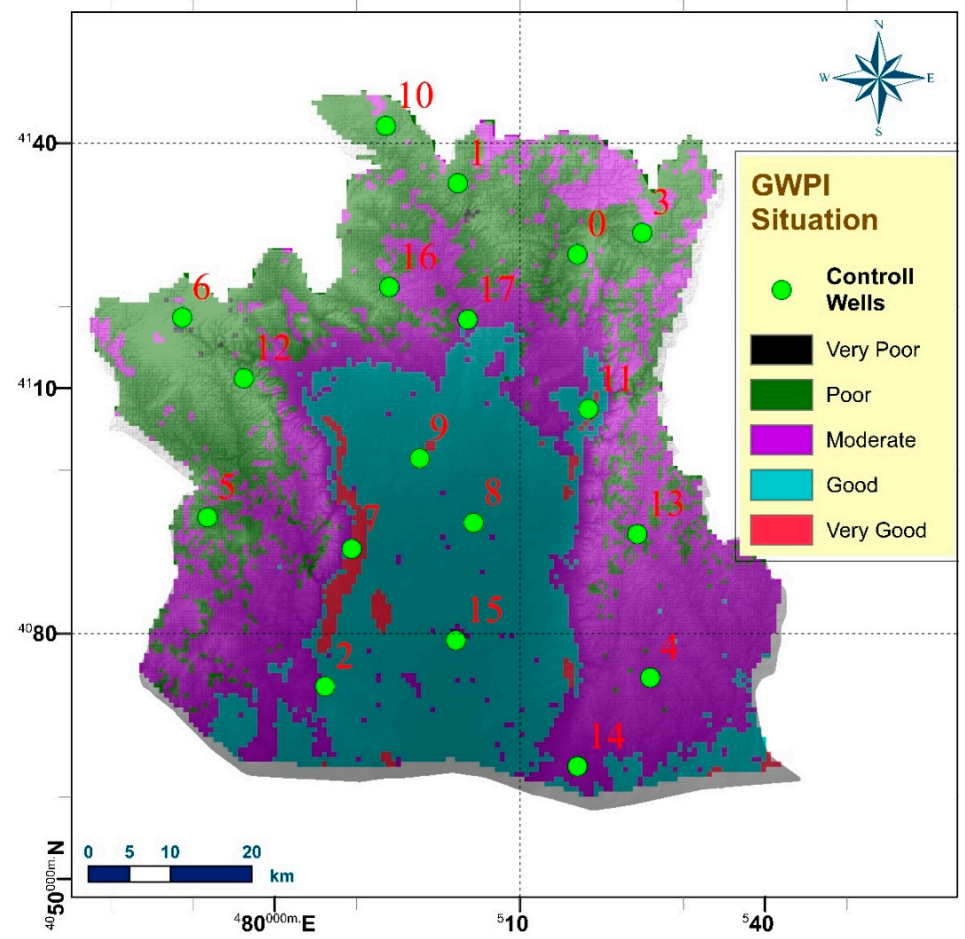

Figure 4. Groundwater Potential Zone (GWPZ) Distribution Map. 
It is calculated according to the AHP method as indicated in Equation (6);

$$
\begin{aligned}
\mathrm{GWPI}=\mathrm{LU}_{\mathrm{r}} \cdot \mathrm{LU}_{\mathrm{w}}+\mathrm{ST}_{\mathrm{r}} \cdot \mathrm{ST}_{\mathrm{w}}+\mathrm{GM}_{\mathrm{r}} \cdot \mathrm{GM}_{\mathrm{w}}+\mathrm{G}_{\mathrm{r}} \cdot \mathrm{G}_{\mathrm{w}}+\mathrm{A}_{\mathrm{r}} \cdot \mathrm{A}_{\mathrm{w}}+\mathrm{DD}_{\mathrm{r}} \cdot \mathrm{DD}_{\mathrm{w}}+\mathrm{R}_{\mathrm{r}} \cdot \mathrm{R}_{\mathrm{w}}+\mathrm{S}_{\mathrm{r}} \cdot \mathrm{S}_{\mathrm{w}} \\
+\mathrm{LD}_{\mathrm{r}} \cdot \mathrm{LD}_{\mathrm{w}}+\mathrm{T}_{\mathrm{r}} \cdot \mathrm{T}_{\mathrm{w}}
\end{aligned}
$$

where GWPI is the Groundwater Potential Index, LU represents the Land Use, ST is the Soil Type, GM is Geomorphology, G is Geology, A is Aquifer, DD is the Drainage Density, R is the Rainfall, $\mathrm{S}$ is the Slope, LD is the Lineament Density, and T is the Terrain Class. In addition, the subscripts " $\mathrm{r}$ " and " $\mathrm{w}$ " refer to the rating and weight of the parameter, respectively.

\section{Results and Discussion}

In this study Land Use, Soil, Geomorphology, Geology, Aquifer, Drainage Density, Rainfall, Slope, Lineament Density, and Terrain Class were taken into consideration. Ten thematic maps were defined to determine the GWPIs. All thematic maps (Figure 3) produced for this study relate to groundwater potential. The general details of these maps are discussed in the following sub-sections. The abstract data are summarized in Table 4.

\begin{tabular}{|c|c|c|c|c|c|c|}
\hline Sequence No. & Parameters & Rank & Sub-Parameters & $\begin{array}{l}\text { Land Coverage } \\
\text { Area }\left(\mathrm{km}^{2}\right)\end{array}$ & $\begin{array}{l}\text { Groundwater } \\
\text { Views }\end{array}$ & Degree \\
\hline \multirow{8}{*}{1} & \multirow{8}{*}{ Land Use } & \multirow{8}{*}{6} & Continuous Irrigated Area & 1414 & Very Good & 9 \\
\hline & & & Woodland & 3 & Very Good & 8 \\
\hline & & & grassland & 1530 & Very Good & 7 \\
\hline & & & Sand Area & 1530 & Good & 7 \\
\hline & & & Wet area & 86 & Moderate & 6 \\
\hline & & & Agriculture, Planting Area & 86 & Moderate & 6 \\
\hline & & & Residential & 82 & Moderate & 5 \\
\hline & & & Agriculture, Fallow Land & 414 & Poor (Weak) & 4 \\
\hline \multirow{4}{*}{2} & \multirow{4}{*}{ Soil } & \multirow{4}{*}{7} & Reddish brown territory & 4497 & Very Good & 8 \\
\hline & & & Brown territory & 516 & Very Good & 7 \\
\hline & & & Other areas & 41 & Good & 6 \\
\hline & & & Basalt lands & 174 & Moderate & 5 \\
\hline \multirow{5}{*}{3} & \multirow{5}{*}{ Geology } & \multirow{5}{*}{8} & $\begin{array}{c}\text { Unspoiled Terrestrial } \\
\text { Crumbs }\end{array}$ & 1986 & Very Good & 8 \\
\hline & & & Basalt & 3049 & Good & 7 \\
\hline & & & Terrestrial Crumbs & 55 & Good & 6 \\
\hline & & & Crumbs and Carbonates & 27 & Moderate & 5 \\
\hline & & & Unassisted Quaternary & 27 & Moderate & 5 \\
\hline \multirow{4}{*}{4} & \multirow{4}{*}{ Geomorphology } & \multirow{4}{*}{8} & Flat & 1768 & Very Good & 9 \\
\hline & & & Plain & 1323 & Good & 7 \\
\hline & & & Plateau & 955 & Moderate & 5 \\
\hline & & & Hill & 1097 & Poor & 3 \\
\hline \multirow{8}{*}{5} & \multirow{8}{*}{ Aquifer Elevation (m) } & \multirow{8}{*}{8} & $810-890$ & 150 & Very Good & 9 \\
\hline & & & $740-810$ & 2229 & Good & 8 \\
\hline & & & $671-740$ & 742 & Good & 7 \\
\hline & & & $601-671$ & 535 & Moderate & 6 \\
\hline & & & $531-601$ & 465 & Moderate & 5 \\
\hline & & & $461-531$ & 740 & Poor & 4 \\
\hline & & & $391-461$ & 215 & Poor & 3 \\
\hline & & & $321-391$ & 68 & Very Poor & 2 \\
\hline \multirow{4}{*}{6} & \multirow{4}{*}{$\begin{array}{l}\text { Drainage Density } \\
\qquad\left(\mathrm{km} / \mathrm{km}^{2}\right)\end{array}$} & \multirow{4}{*}{5} & $0-1$ & 42 & Good & 7 \\
\hline & & & $2-4$ & 45 & Moderate & 5 \\
\hline & & & $5-7$ & 48 & Poor & 3 \\
\hline & & & $8-12$ & 5009 & Very Poor & 1 \\
\hline \multirow{3}{*}{7} & \multirow{3}{*}{ Rainfall (mm/year) } & \multirow{3}{*}{9} & $318-331$ & 1754 & Poor & 3 \\
\hline & & & $331-350$ & 1964 & Moderate & 4 \\
\hline & & & $350-381$ & 4521 & Moderate & 5 \\
\hline
\end{tabular}

Table 4. Details of the layers of the research area. 
Table 4. Cont.

\begin{tabular}{|c|c|c|c|c|c|c|}
\hline Sequence No. & Parameters & Rank & Sub-Parameters & $\begin{array}{c}\text { Land Coverage } \\
\text { Area }\left(\mathrm{km}^{2}\right)\end{array}$ & $\begin{array}{c}\text { Groundwater } \\
\text { Views }\end{array}$ & Degree \\
\hline \multirow{5}{*}{8} & \multirow{5}{*}{ Slope (\%) } & \multirow{5}{*}{8} & $0.00-1.50$ & 1791 & Very Good & 9 \\
\hline & & & $1.50-3.00$ & 2322 & Very Good & 8 \\
\hline & & & $3.00-4.50$ & 945 & Good & 7 \\
\hline & & & $4.50-6.00$ & 66 & Moderate & 5 \\
\hline & & & $6.00-9.41$ & 20 & Poor & 3 \\
\hline \multirow{4}{*}{9} & \multirow{4}{*}{$\begin{array}{l}\text { Fault Density } \\
\left(\mathrm{km} / \mathrm{km}^{2}\right)\end{array}$} & \multirow{4}{*}{4} & $0.00-15.29$ & 42 & Good & 7 \\
\hline & & & $15.29-30$ & 45 & Moderate & 5 \\
\hline & & & $30-50$ & 48 & Poor & 3 \\
\hline & & & $50-70$ & 5009 & Very Poor & 1 \\
\hline \multirow{6}{*}{10} & \multirow{6}{*}{ Terrain Class } & \multirow{6}{*}{6} & $\mathrm{I}$ & 1662 & Moderate & 5 \\
\hline & & & II & 323 & Moderate & 4 \\
\hline & & & III & 581 & Poor & 3 \\
\hline & & & IV & 317 & Very poor & 2 \\
\hline & & & $\mathrm{VI}$ & 400 & Very good & 8 \\
\hline & & & VII & 1861 & Very & 9 \\
\hline
\end{tabular}

\subsection{Land Use}

ArcGIS was used to determine the models of the research area. The details of the classifications of use of land are given in Table 4 and illustrated in Figure 3a. High weight values were determined for the perennially irrigated lands, forested lands, forages, and sandy areas. For the wetted areas and cultivated areas, good weight values were determined. Since the settled areas and the settlements impede rainfall infiltration, they prevent water from reaching the underground reservoirs [53]; therefore, lower weight values were given to the settlement areas, cultivated areas, and fallow lands. Besides, in irrigated cropland occurs more uniform infiltration. The low-stem water clutch in fallow fields during wet winters results in a higher recharge flow through the reservoirs, which flushes salt deposits from the vadose zones [54].

\subsection{Soil Type}

Soil plays an important role in mapping the areas with groundwater potential. For example, soil types with thick layers are generally permeable, while fine-textured soils are less permeable. The soil types with higher permeability allow for a higher infiltration rate-in this case, most of the rainfall waters can reach the groundwater layer faster [55]. The soil map of the research area was obtained from the Administration of Disaster and Emergency Management, Şanlıurfa, Turkey. The soil map of the research area was classified using the following categories: reddish brown soils, brown soils, other areas, and basalt soils (Figure 3). The soil types and their percentages by area are given in Table 4 .

The majority of the research area is composed of reddish-brown soil $\left(4497 \mathrm{~km}^{2}\right)$, brown soil $\left(516 \mathrm{~km}^{2}\right)$, and basalt soil $\left(174 \mathrm{~km}^{2}\right)$.

\subsection{Geomorphology}

Geomorphology, which describes the formation process of a region, uses maps that provide information about the geographical formations resulting from internal and external forces [56]. The geomorphology map is classified into four sections. The majority of the region is composed of plains - particularly to the north, toward Şanlıurfa-and smooth lands to the south, ending with partial hills in the southeast (Figure 3). Since the slope is lower on the plains, underground infiltration is more significant. In the mountainous and hilly regions, the runoff is even greater. Therefore, the scoring of the smooth and plain lands was high, while the scoring of the mountainous lands was low.

\subsection{Geology}

The Harran Plain experienced some faulting and subsidence events resulting from the Karacadağ volcano following the Eocene and Miocene periods. While units of large 
particles of silt, sand, and pebble materials are present on the borders of the basin, materials with a high clay content can be found toward the center of the basin. Within the aggregation of class at the center of the plain, there are lens-shaped permeable units (silt, sand, and pebbles) formed by various causes [30]. These permeable units appear as separate and independent lens-shaped units throughout the plain, rather than as a unified whole (Figure 3). The ratings of areas with geological characteristics of sand and pebbles were higher, while ratings of the clayey layers were lower.

\subsection{Aquifers}

The formation and mobility of the groundwater is controlled through porosity, permeability, the structure of the aquifers, aquifer distribution, feeding areas, and the use of aquifers [57]. Eocene-period limestone provides the bore holes for the main aquifers. The depth maps of the aquifers were obtained from the difference between the static level and the height of the land. The ratings were higher for areas with lower aquifer depths. The greater the depth, the lower the scores.

\subsection{Drainage Density}

The drainage densities of the basins cause the majority of rainfall to become runoff [58]. Lower drainage-density values are more appropriate for high groundwater potential and weights. Moreover, a lower drainage density indicates a higher infiltration of rainfall. The drainage density was obtained by dividing the basin area by the unit length:

$$
D D=D L / D A
$$

where $D D$ is Drainage Density, $D L$ is Drainage Length, and $D A$ is the Drainage Unit Area. In general, the groundwater potential increases from the south of the research area to the north due to the lower drainage density (Figure 3).

\subsection{Rainfall}

We used district-level average annual rainfall values (latitude/longitude) obtained from the Şanlıurfa Regional Directorate of Meteorology based on the meteorological data between 1929 and 2017. Since the station-location data of the districts are present in the geographical coordinate system, the rainfall data of the stations were used in the ArcGIS environment. We obtained contour rainfall maps with these data by using Arc Map, Spatial Analysis, and IDW methods. These vectorial maps were initially classified into raster maps and subsequently reclassified according to their impact scores (Figure 3). Since the region is located in a semi-arid climate zone, the region does not experience significant rainfall. The rainfall values vary between 264 and $365 \mathrm{~mm} /$ year. Regions with an average of 330-365 mm/year scored 6 points, regions with an average rainfall of 300-330 mm/year scored 5 points, and regions with an average rainfall below $300 \mathrm{~mm} /$ year (Table 4) scored 4 points. Overall, rainfall is scarce in this region. However, we considered nine criteria in the area where Rainfall has the maximum score, although the recharge of the aquifer will be slow, and the possibility of overexploitation will be greater.

\subsection{Slope}

Rainfall-based infiltration is an important hydrological parameter for determining groundwater potential [59]. Infiltration depends on characteristics such as the type of the soil, vegetation, and slope. When there is a high slope, no ponds occur on the soil. The slope map was obtained from the DEM through the CBS method. Ultimately, since the research area is smooth, the slope is not great. The research area is flat, which indicates a high potential for the formation of groundwater. Figure 3 illustrated the slope maps classified by research area. The scoring of these maps is shown in Table 4. 


\subsection{Fault Density}

The fault line of the planet is used here as the wide linear underground characteristic, which increases the direct porosity and is used as a diffraction line [60]. The lines are the manifestations of linear features that can play important roles in determining the appropriate areas for groundwater feeding [12]. Lineaments facilitate the mobility of the groundwater. The fault density maps were drawn by means of DEM maps and fault lines. The fault density maps of the research area are shown in Figure 3 and were classified based on five categories. The fault density is highest towards the east and west of the research area, as indicated in red. However, the fault density was found to be low in other regions. The basin has a level of density that increases the groundwater porosity and the permeability of the area. Thus, the weights are higher, indicating groundwater potential.

\subsection{Terrain Structure}

A change in the land cover influences the runoffs [61], the water intake speed [62], and the vaporization from the soil surface [63]. As shown in Figure 3, the structure of the land was classified into six groups. The majority of the land (36\%) is VIIth class land, which has the highest scores for groundwater feeding and infiltration. The second-highest score belongs to the VIth class land, which is distributed in $8 \%$ of the area. Thirty-two percent of the land is Ist class land, with a rating of 5 (moderate). Six percent of the area is IInd class land, and $11 \%$ is IIIrd class land, which has the lowest ratings.

\subsection{The Distribution of the Groundwater Potential Regional Map}

The GWPI value was obtained through multi-assessment transactions of the MultiCriteria Decision System based on ten parameters: Land Structure, Use of Land, Geology, Soil, Geomorphology, Rainfall, Fault density, Drainage density, Slope, and Aquifer criteria. The Groundwater Potential Zone (GWPZ) was determined by classifying its value (Figure 4).

In this thematic map, the GWPI value varies between 370 and 617. Table 5 outlines the classification ranges and the total classification ratings on a basin-basis according to the GWPZ values. As shown in Figure 4, in the central Harran Basin (and partially to the south), the groundwater potential is at a good level. However, particularly in the northern areas, the groundwater potential is at a moderate level.

Table 5. Classification of the Harran Basin according to the GWPI values.

\begin{tabular}{cccc}
\hline GWPI Values & Definition & Rating $\mathbf{( \% )}$ & Area $\left.\mathbf{( k m}^{\mathbf{2}}\right)$ \\
\hline $307-340$ & Very Poor & 0.10 & 5.14 \\
\hline $340-445$ & Poor & 29.20 & 1501.17 \\
\hline $445-530$ & Moderate & 38.20 & 1963.86 \\
\hline $530-580$ & Good & 30.90 & 1588.57 \\
\hline $580-617$ & Very Good & 1.50 & 77.12 \\
\hline
\end{tabular}

\subsection{Validity}

To validate the groundwater area map, we used data from the 18 water observation wells (Table 6) within the borders of the basin. The GWPZ map in Figure 4 illustrates the groundwater research area map together with the locations of the water wells. The groundwater potential areas of almost all the existing pumping wells for irrigation were evaluated according to the following categories: very good, good, moderate, poor, and very poor. Based on this classification, the reference data for only 2 of the 18 wells were determined to be partially compatible. Among these wells, 16 references were found to be completely compatible with the study classification. 
Table 6. Comparison of the data for the wells and the GWPI.

\begin{tabular}{|c|c|c|c|c|c|c|c|c|c|c|}
\hline $\begin{array}{l}\text { Reference } \\
\text { Number }\end{array}$ & $X$ & $\mathbf{Y}$ & $\mathbf{Z}$ & Depth & SWL & DWL & Yield & GWPI & Evaluation & Compliance \\
\hline 0 & 517,053 & $4,126,396$ & 693 & 290 & 175 & 235 & 1,5 & 396 & Poor & Compatible \\
\hline 1 & 502,400 & $4,135,099$ & 760 & - & 110 & 165 & 1,5 & 435 & Poor & Compatible \\
\hline 2 & 486,164 & $4,073,547$ & 393 & 110 & 70 & 80 & 10 & 568 & Good & Compatible \\
\hline 3 & 524,961 & $4,129,044$ & 725 & - & 85 & 132 & 1 & 428 & Poor & Compatible \\
\hline 4 & 525,951 & $4,074,609$ & 480 & 205 & 160 & 180 & 10 & 574 & Good & Compatible \\
\hline 5 & 471,773 & $4,094,228$ & 609 & 254 & 120 & 175 & 2 & 435 & Poor & Compatible \\
\hline 6 & 468,680 & $4,118,684$ & 713 & 180 & 90 & 150 & 1,5 & 380 & Poor & Compatible \\
\hline 7 & 489,424 & $4,090,377$ & 388 & 200 & 60 & 100 & 6 & 576 & Good & Compatible \\
\hline 8 & 504,327 & $4,093,563$ & 384 & 170 & 3 & 64 & 10 & 561 & Good & Compatible \\
\hline 9 & 497,742 & $4,101,438$ & 422 & 220 & 40 & 110 & 10 & 577 & Good & Compatible \\
\hline 10 & 493,394 & $4,142,126$ & 798 & 250 & 60 & 180 & 1 & 419 & Poor & Compatible \\
\hline 11 & 518,388 & $4,107,470$ & 466 & 220 & 50 & 150 & 5 & 556 & Good & Compatible \\
\hline 12 & 476,215 & $4,111,228$ & 695 & 250 & 130 & 200 & 10 & 431 & Poor & $\begin{array}{c}\text { Partially } \\
\text { Compatible }\end{array}$ \\
\hline 13 & 524,371 & $4,092,163$ & 611 & 330 & 280 & 300 & 5 & 462 & Moderate & Compatible \\
\hline 14 & 517,047 & $4,063,762$ & 422 & 160 & 130 & 160 & 4 & 509 & Moderate & Compatible \\
\hline 15 & 502,164 & $4,079,184$ & 382 & 180 & 140 & 170 & 10 & 561 & Good & Compatible \\
\hline 16 & 494,024 & $4,122,396$ & 661 & 180 & 50 & 100 & 9 & 454 & Moderate & $\begin{array}{c}\text { Partially } \\
\text { Compatible }\end{array}$ \\
\hline 17 & 503,607 & $4,118,421$ & 524 & 150 & 25 & 120 & 3 & 435 & Poor & Compatible \\
\hline
\end{tabular}

Accuracy rate: compatible wells number/all references wells number: $16 / 18=88.9 \%$.

In the basin, an area of $5.14 \mathrm{~km}^{2}$ had very poor groundwater potential $(0.1 \%)$, an area of $1501 \mathrm{~km}^{2}$ had poor potential $(29 \%)$, an area of $1963 \mathrm{~km}^{2}$ had moderate potential $(38 \%)$, an area of $1589.5 \mathrm{~km}^{2}$ had good potential $(31 \%)$, and an area of $77.12 \mathrm{~km}^{2}$ had very good potential. The 18 observation wells yielded performance and locations in the research area that were related to the groundwater potential area map and presented good compliance, with $88.9 \%$ accuracy. Similar studies using similar methods in various regions achieved varying results. Ghosh et al. studied the upper Kangsabati river basin; the result of the overall accuracy assessment was $79.77 \%$, which supports the validity of the study. The authors also claimed that slope was most dominant factor among the seven selected hydro-geological factors that influence the occurrence of groundwater [64]. Zhu and Abdelkareem (2021) determined that the groundwater potential zones of East Indian regions contain nearly $40 \%$ land with very high potential. The downstream areas and Wadi Garara were, moreover, shown to have very high recharge and storage potential. This study also indicated that about $86.17 \%$ of the observation wells could be matched with very good to moderate potential zones under this method [65]. Mukherjee and Singh applied this method with an accuracy of $80.48 \%$ in their study on the arid regions of Western India [66]. Zaidi et al. (2015) focused on identifying the potential zones of Artificial Groundwater Recharge (AGR) in northwestern Saudi Arabia. The results showed that $17.90 \%$ of the total studied area was suitable for AGR [28].

\section{Conclusions}

The Mesopotamian Basin is a region where agricultural activities have been carried out since the beginning of civilization. The Harran Plain is a sub-basin of the Euphrates, where the wheat was harvested for the first time in ancient Mesopotamia. Including irrigation 
in an area's agricultural activities increases crop yields, and utilizing surface water via dams could be one of the most useful irrigation methods. However, in places where this method is unfeasible, irrigation via groundwater resources is becoming widespread. One possible method of observation uses wells drilled into narrow and tiny areas to determine the potential of the groundwater. However, this method is inappropriate for large-scale plains because it has long-lasting effects and is economically unsustainable. Instead of this method, it is possible to produce a map of groundwater potential by modeling, in wider areas, the impact rates of the factors forming the groundwater. A parametric approach utilizing the techniques of RS, GIS, and AHP could reduce the time, labor, and costs to their minimum levels, thereby enabling faster decisions for the productive management of water resources. Despite the limitations inherent to multi-criteria analysis, this type of analysis represents a valuable and practical tool for areas and regions (especially in developing states) that suffer from challenges in determining water solutions due to data scarcity (both in terms of quality and quantity).

The present study outlined a methodology using RS, GIS, and MCDM techniques to identify the charge regions and determine the potential charge areas from the Harran Plain sub-basin to the Euphrates Basin, located in the south-eastern part of Turkey. To prepare the thematic layers of permeability, we used Land Use, Geology, Geomorphology, Drainage Density, Lineament Density, Slope, Soil, Aquifer, and Terrain data. Finally, we determined appropriate charge areas by overlapping the artificial charge region map, second- and third-degree drainage maps, and graphical maps. According to the charge region map, the middle and southern areas of the plain are, respectively, suitable (31\%) and moderately suitable $(37 \%)$. We determined that the region is a plain with a low slope and geologically consists of limestone. Notably, the areas with poor water potential were found to be mountainous and hilly, and the slopes over these areas are high. Therefore, the features of topography, slopes, and aquifers are more active parameters than the other parameters of groundwater potential. The groundwater potential maps can be effectively used to manage the aquifer in a sustainable way and drill new wells in the high-potential maps. The well-yield performance and locations in the research area are related to the groundwater potential area map and show good compliance. The groundwater potential area map obtained in this study would also be appropriate for future sustainable groundwater development plans.

Author Contributions: Supervision: R.Ç.; Investigation: V.A. Both authors have read and agreed to the published version of the manuscript.

Funding: This research received no external funding.

Conflicts of Interest: The authors declare no conflict of interest.

\section{References}

1. Kürkçüoğlu, A.C. İnançlar Diyarı Şanlıurfa; Şanlıurfa Valiliği Kültür Yayınları: Şanlıurfa, Turkey, 2000.

2. Çelik, B. An early neolithic settlement in the center of Sanliurfa, Turkey. Neo-Lithic 2000, 2-3, 4-6.

3. Benek, S. GAP Bölgesi'nde tarımsal faaliyetlerin tarihsel gelişimi ve günümüzdeki durumu. Marmara Coğrafya Derg. 2012, 195-215.

4. Şahinalp, M.S. Şanlıurfa şehri'nin kuruluşuna etki eden etmenler. Coğrafi Bilimler Derg. 2006, 4, 105-127.

5. Şahin, G.; Taşlıgil, N. Güneydoğu Anadolu Projesi (GAP)'nin dünü bugünü yarını. Akademik Bakış 2013, 36.

6. Bilgen, A. 1977'den 2017'ye güneydoğu anadolu projesi (GAP): GAP'ın 40 yılı üzerine nitel ve çok boyutlu bir değerlendirme. Ankara Üniversitesi SBF Dergisi 2018, 73, 811-840.

7. Yu, H.L.; Chu, H.-J. Recharge signal identification based on groundwater level observations. Environ. Monit. Assess. 2011, 184, 5971-5982. [CrossRef] [PubMed]

8. Halder, S.; Roy, M.B.; Roy, P.K. Analysis of groundwater level trend and groundwater drought using Standard Groundwater Level Index: A case study of an eastern river basin of West Bengal, India. SN Appl. Sci. 2020, 2, 1-24. [CrossRef]

9. Chu, H.-J. Drought detection of regional nonparametric standardized groundwater index. Water Resour. Manag. 2018, 32, 3119-3134. [CrossRef]

10. Sophocleous, M. Review: Groundwater management practices, challenges, and innovations in the High Plains aquifer, USAlessons and recommended actions. Hydrogeol. J. 2009, 18, 559-575. [CrossRef] 
11. Shah, T. Groundwater and human development: Challenges and opportunities in livelihoods and environment. Water Sci. Technol. 2005, 51, 27-37. [CrossRef]

12. Chung, I.-M.; Kim, Y.J.; Kim, N.W. Estimating the temporal distribution of groundwater recharge by using the transient water table fluctuation method and watershed hydrologic model. Appl. Eng. Agric. 2021, 37, 95-104. [CrossRef]

13. Danielopol, D.L.; Griebler, C.; Gunatilaka, A.; Notenboom, J. Present state and future prospects for groundwater ecosystems. Environ. Conserv. 2003, 30, 104-130. [CrossRef]

14. Morris, B.L.; Lawrence, A.R.; Chilton, P.J.C.; Adams, B.; Calow, R.C.; Klinck, B.A. Groundwater and its Susceptibility to Degradation: A Global Assessment of the Problem and Options for Management; United Nations Environment Programme: Nairobi, Kenya, 2003.

15. De Stefano, L.; Lopez-Gunn, E. Unauthorized groundwater use: Institutional, social and ethical considerations. Hydrol. Res. 2012, 14, 147-160. [CrossRef]

16. Chowdhury, A.; Jha, M.K.; Chowdary, V.M. Delineation of groundwater recharge zones and identification of artificial recharge sites in West Medinipur district, West Bengal, using RS, GIS and MCDM techniques. Environ. Earth Sci. 2010, 59, 1209-1222. [CrossRef]

17. Rahmati, O.; Samani, A.N.; Mahdavi, M.; Pourghasemi, H.R.; Zeinivand, H. Groundwater potential mapping at Kurdistan region of Iran using analytic hierarchy process and GIS. Arab. J. Geosci. 2015, 8, 7059-7071. [CrossRef]

18. Çelik, R. Evaluation of Groundwater Potential by GIS-Based Multicriteria Decision Making as a Spatial Prediction Tool: Case Study in the Tigris River Batman-Hasankeyf Sub-Basin, Turkey. Water 2019, 11, 2630. [CrossRef]

19. Srivastava, P.K.; Bhattacharya, A.K. Groundwater assessment through an integrated approach using remote sensing, GIS and resistivity techniques: A case study from a hard rock terrain. Int. J. Remote Sens. 2006, 27, 4599-4620. [CrossRef]

20. Prasad, R.K.; Mondal, N.; Banerjee, P.; Nandakumar, M.V.; Singh, V.S. Deciphering potential groundwater zone in hard rock through the application of GIS. Environ. Earth Sci. 2008, 55, 467-475. [CrossRef]

21. Çelik, R. Temporal changes in the groundwater level in the Upper Tigris Basin, Turkey, determined by a GIS technique. J. Afr. Earth Sci. 2015, 107, 134-143. [CrossRef]

22. Adiat, K.; Nawawi, M.; Abdullah, K. Assessing the accuracy of GIS-based elementary multi criteria decision analysis as a spatial prediction tool-A case of predicting potential zones of sustainable groundwater resources. J. Hydrol. 2012, 440-441, 75-89. [CrossRef]

23. Agarwal, E.; Agarwal, R.; Garg, R.; Garg, P.K. Delineation of groundwater potential zone: An AHP/ANP approach. J. Earth Syst. Sci. 2013, 122, 887-898. [CrossRef]

24. Agarwal, R.; Garg, P. Remote Sensing and GIS Based Groundwater Potential \& Recharge Zones Mapping Using Multi-Criteria Decision Making Technique. Water Resour. Manag. 2016, 30, 243-260.

25. Madrucci, V.; Taioli, F.; de Araújo, C.C. Groundwater favorability map using GIS multicriteria data analysis on crystalline terrain, São Paulo State, Brazil. J. Hydrol. 2008, 357, 153-173. [CrossRef]

26. Kumar, T.; Gautam, A.K.; Kumar, T. Appraising the accuracy of GIS-based multi-criteria decision making technique for delineation of groundwater potential zones. Water Resour. Manag. 2014, 28, 4449-4466. [CrossRef]

27. Dhar, A.; Sahoo, S.; Dey, S.; Sahoo, M. Evaluation of Recharge and Groundwater Dynamics of a Shallow Alluvial Aquifer in Central Ganga Basin, Kanpur (India). Nat. Resour. Res. 2014, 23, 409-422. [CrossRef]

28. Zaidi, F.K.; Nazzal, Y.; Ahmed, I.; Naeem, M.A.; Jafri, M.K. Identification of potential artificial groundwater recharge zones in Northwestern Saudi Arabia using GIS and Boolean logic. J. Afr. Earth Sci. 2015, 111, 156-169. [CrossRef]

29. Pinto, D.; Shrestha, S.; Babel, M.S.; Ninsawat, S. Delineation of groundwater potential zones in the Comoro watershed, Timor Leste using GIS, remote sensing and analytic hierarchy process (AHP) technique. Appl. Water Sci. 2017, 7, 503-519. [CrossRef]

30. DSİ (Devlet Su İşleri). Harran Ovası Hidrojeolojik Etüdü; DSI: Ankara, Turkey, 1972; p. 49.

31. Celik, R.; Aslan, V. Evaluation of hydrological and hydrogeological characteristics affecting the groundwater potential of Harran Basin. Arab. J. Geosci. 2020, 13, 1-13. [CrossRef]

32. Atasoy, A.D.; Yesilnacar, M.I. Effect of high sulfate concentration on the corrosivity: A case study from groundwater in Harran Basin, Turkey. Environ. Monit. Assess. 2010, 166, 595-607. [CrossRef]

33. Çullu, M.A.; Aydemir, S.; Qadir, M.; Almaca, A.; Öztürkmen, A.R.; Bilgic, A.; Ağca, N. Implication of groundwater fluctuation on the seasonal salt dynamic in the Harran Basin, south-eastern Turkey. Irrig. Drain. 2010, 59, 465-476. [CrossRef]

34. Ucar, D.; Cokgor, E.U.; Sahinkaya, E.; Cetin, U.; Bereketoglu, C.; Calimlioglu, B.; Goncu, B.; Yurtsever, A. Simultaneous nitrate and perchlorate removal from groundwater by heterotrophic-autotrophic sequential system. Int. Biodeterior. Biodegrad. 2017, 116, 83-90. [CrossRef]

35. Yesilnacar, M.I.; Gulluoglu, M.S. Hydrochemical characteristics and the effects of irrigation on groundwater quality in Harran Basin, GAP Project, Turkey. Environ. Geol. 2008, 54, 183-196. [CrossRef]

36. Tardu, T.; Başkurt, T.; Güven, A.; Us, E.; Dinçer, A.; Tuna, M.E.; Tezcan, U.S. Akçakale Grabeni'nin Yapısal-Stratigrafik Özellikleri ve Petrol Potansiyeli. Türkiye 1987, 7, 6-10.

37. Jha, M.K.; Bongane, G.M.; Chowdary, V.M. Groundwater potential zoning by remote sensing, GIS and MCDM techniques: A case study of eastern India. In Hydroinformatics in Hydrology, Hydrogeology and Water resources, Proceedings of the Symposium JS. 4 at the Joint Convention of the International Association of Hydrological Sciences (IAHS) and the International Association of Hydrogeologists (IAH) held in Hyderabad, India, 6-12 September 2009; IAHS Press: Wallingford, UK, 2009; pp. 432-441. 
38. Mehrabi, H.; Zeinivand, H.; Hadidi, M. Site selection for groundwater artificial recharge in Silakhor Rangelands Using GIS Technique. J. Rangel. Sci. 2013, 2, 687-695.

39. Nithya, C.N.; Srinivas, Y.; Magesh, N.; Kaliraj, S. Assessment of groundwater potential zones in Chittar basin, Southern India using GIS based AHP technique. Remote Sens. Appl. Soc. Environ. 2019, 15, 100248. [CrossRef]

40. Patra, S.; Mishra, P.; Mahapatra, S.C. Delineation of groundwater potential zone for sustainable development: A case study from Ganga Alluvial Plain covering Hooghly district of India using remote sensing, geographic information system and analytic hierarchy process. J. Clean. Prod. 2018, 172, 2485-2502. [CrossRef]

41. Saidi, S.; Hosni, S.; Mannai, H.; Jelassi, F.; Bouri, S.; Anselme, B. GIS-based multi-criteria analysis and vulnerability method for the potential groundwater recharge delineation, case study of Manouba phreatic aquifer, NE Tunisia. Environ. Earth Sci. 2017, 76, 511. [CrossRef]

42. Dhar, A.; Sahoo, S.; Mandal, U.; Dey, S.; Bishi, N.; Kar, A. Hydro-environmental assessment of a regional groundwater aquifer: Hirakud command area (India). Environ. Earth Sci. 2015, 73, 4165-4178. [CrossRef]

43. Brahim-Bathis, K.; Ahmed, S. Geospatial technology for delineating groundwater potential zones in Doddahalla watershed of Chitradurga district, India. Egypt. J. Remote Sens. Space Sci. 2016, 19, $223-234$.

44. Sikdar, P.K.; Chakraborty, S.; Adhya, E.; Paul, P.K. Land use/Land cover changes and groundwater potential zoning in and around Raniganj coal mining area, Bardhaman District, West Bengal-A GIS and Remote Sensing Approach. J. Spatial Hydrol. 2004, $4,1-24$

45. Yin, H.; Shi, Y.; Niu, H.; Xie, D.; Wei, J.; Lefticariu, L.; Xu, S. A GIS-based model of potential groundwater yield zonation for a sandstone aquifer in the Juye Coalfield, Shangdong, China. J. Hydrol. 2018, 557, 434-447. [CrossRef]

46. Senanayake, I.; Dissanayake, D.; Mayadunna, B.; Weerasekera, W. An approach to delineate groundwater recharge potential sites in Ambalantota, Sri Lanka using GIS techniques. Geosci. Front. 2016, 7, 115-124. [CrossRef]

47. Russell, R.S.; Taylor, B.W. Operations Management; Prentice Hall: Upper Saddle River, NJ, USA, 2003 ; Volume 3.

48. Saaty, T.L. The Analytic Hierarchy Process; McGraw-Hill: New York, NY, USA, 1980.

49. Saaty, T.L. Hierarchical-multi objective systems. Control Theory Adv. Technol. 1989, 5, 485-489.

50. Saaty, T.L. Decision-making with the AHP: Why is the principal eigenvector necessary. Eur. J. Oper. Res. 2003, 145, 85-91. [CrossRef]

51. Alonso, J.A.; Lamata, M.T. Consistency in the analytic hierarchy process: A new approach. Int. J. Uncertainty Fuzziness Knowl. Based Syst. 2006, 14, 445-459. [CrossRef]

52. Shekhar, S.; Pandey, A.C. Delineation of groundwater potential zone in hard rock terrain of India using remote sensing, geographical information system (GIS) and analytic hierarchy process (AHP) techniques. Geocarto Int. 2014, 30, 402-421. [CrossRef]

53. Scanlon, B.R.; Reedy, R.C.; Stonestrom, D.; Prudic, D.E.; Dennehy, K.F. Impact of land use and land cover change on groundwater recharge and quality in the southwestern US. Glob. Chang. Biol. 2005, 11, 1577-1593. [CrossRef]

54. Kurtzman, D.; Scanlon, B.R. Groundwater Recharge through Vertisols: Irrigated Cropland vs. Natural Land, Israel. Vadose Zone J. 2011, 10, 662-674. [CrossRef]

55. Schrick, B.; Hydutsky, B.W.; Blough, J.L.; Mallouk, T.E. Delivery vehicles for zerovalent metal nanoparticles in soil and groundwater. Chem. Mater. 2004, 16, 2187-2193. [CrossRef]

56. Birkeland, P.W. Soils and Geomorphology; Oxford University Press: Oxford, UK, 1984.

57. Bouwer, H.; Bouwer, H. Groundwater Hydrology; McGraw-Hill: New York, NY, USA, 1978; Volume 480.

58. Gupta, M.; Srivastava, P.K. Integrating GIS and remote sensing for identification of groundwater potential zones in the hilly terrain of Pavagarh, Gujarat, India. Water Int. 2010, 35, 233-245. [CrossRef]

59. Batelaan, O.; De Smedt, F. WetSpass: A Flexible, GIS Based, Distributed Recharge Methodology for Regional Groundwater Modelling; IAHS Press: Wallingford, UK, 2001; pp. 11-18.

60. Avtar, R.; Singh, C.K.; Shashtri, S.; Singh, A.; Mukherjee, S. Identification and analysis of groundwater potential zones in Ken-Betwa river linking area using remote sensing and geographic information system. Geocarto. Int. 2010, 25, 379-396. [CrossRef]

61. Sajikumar, N.; Remya, R. Impact of land cover and land use change on runoff characteristics. J. Environ. Manag. 2015, 161, 460-468. [CrossRef] [PubMed]

62. Ghimire, C.P.; Bruijnzeel, L.A.; Lubczynski, M.W.; Bonell, M. Negative trade-off between changes in vegetation water use and infiltration recovery after reforesting degraded pasture land in the Nepalese Lesser Himalaya. Hydrol. Earth Syst. Sci. 2014, 18, 4933-4949. [CrossRef]

63. Metzger, J.C.; Landschreiber, L.; Gröngröft, A.; Eschenbach, A. Soil evaporation under different types of land use in southern African savanna ecosystems. J. Plant Nutr. Soil Sci. 2014, 177, 468-475. [CrossRef]

64. Ghosh, D.; Mandal, M.; Banerjee, M.; Karmakar, M. Impact of hydro-geological environment on availability of groundwater using analytical hierarchy process (AHP) and geospatial techniques: A study from the upper Kangsabati river basin. Groundw. Sustain. Dev. 2020, 11, 100419. [CrossRef] 
65. Zhu, Q.; Abdelkareem, M. Mapping Groundwater Potential Zones Using a Knowledge-Driven Approach and GIS Analysis. Water 2021, 13, 579. [CrossRef]

66. Mukherjee, I.; Singh, U.K. Delineation of groundwater potential zones in a drought-prone semi-arid region of east India using GIS and analytical hierarchical process techniques. Catena 2020, 194, 104681. [CrossRef] 